Steve L. Brown

Department of Entomology, University of Georgia, Tifton

\author{
Albert K. Culbreath \\ Department of Plant Pathology, University of \\ Georgia, Tifton \\ James W. Todd \\ Department of Entomology, University of Georgia, \\ Tifton
}

Dan W. Gorbet

Department of Agronomy, University of Florida, Marianna

\author{
John A. Baldwin \\ Department of Crop and Soil Sciences, University \\ of Georgia, Tifton
}

John P. Beasley, Jr.

Department of Crop and Soil Sciences, University of Georgia, Tifton

\title{
Development of a Method of Risk Assessment to Facilitate Integrated Management of Spotted Wilt of Peanut
}

\begin{abstract}
Tomato spotted wilt virus (TSWV) is one of a growing list of tospoviruses adversely affecting agriculture worldwide $(36,38)$. Spotted wilt, the disease caused by TSWV, was first observed in peanut (Arachis hypogaea L.) growing regions of the southeastern United States in 1986 (41), and its importance steadily increased in Georgia through 1997 to the extent that annual losses exceeded \$40 million. Since 1997, annual losses have sharply declined to approximately $\$ 10$ million in 2000 (60) and \$3.3 million in 2003 (15).
\end{abstract}

The only known means of virus transmission is via vectors belonging to a few species of thrips $(36,50)$. Only first instar larvae of Frankliniella occidentalis (Pergande), one vector species, can acquire the virus from an infected plant (57). After acquisition, the virus replicates in the vector and the viruliferous thrips is capable of transmission for the duration of its life $(50,56,59)$. In Georgia, the primary vectors are tobacco thrips, F. fusca (Hinds), and western flower thrips, $F$. occidentalis (53). Most spotted wilt in peanut is thought to be the result of primary transmission, but some secondary transmission probably occurs as well (22), mostly by $F$. fusca, which readily reproduces on peanut $(53,54)$.

Corresponding author: Steve L. Brown

E-mail: bugbrown@arches.uga.edu

DOI: 10.1094/PD-89-0348

() 2005 The American Phytopathological Society
Peanut plants may initiate symptom expression at any stage of plant development (6), but severe stunting (Fig. 1) typically occurs on younger plants, whereas the initiation of symptoms on older plants typically results in generalized yellowing and/or localized leaf mottling (Fig. 2). Linear regression indicates that both number of seed and seed yield per infected plant increase with time from planting until symptom expression (27).

Incidence and severity of tomato spotted wilt of peanut have been extremely variable in Georgia peanut fields (11). Research programs conducted since 1990 have identified several contributing factors affecting disease severity and have provided estimates of their relative importance. Some factors are more important than others, but no single factor can be manipulated to control the disease (26). Using available research data, a spotted wilt risk index was developed as a means of helping peanut growers to assess risk levels associated with specific combinations of production practices and thereby to avoid high-risk situations. Pertinent production practices were assigned point values that were weighted relative to their influence on final spotted wilt severity. As new research data became available, the index was modified and validated with extensive small plot trials and on-farm surveys. This article describes how the index was developed and modified and reports the results of on-farm surveys used to validate the index for peanut grown under a wide array of production practices.

\section{Factors Affecting Severity of Tomato Spotted Wilt in Peanut}

Peanut cultivar. Soon after spotted wilt became established in Georgia, the cultivar 'Southern Runner' was noted to have about half the incidence of that seen on the more widely grown 'Florunner' $(5,28)$. This serendipitous discovery was followed by the discovery of a series of other varieties, some of which were produced from crosses with 'Southern Runner', having similar levels of resistance. 'Georgia Browne' (25), 'Georgia Green' (29), 'Florida MDR 98' (32), 'ViruGard' (31), 'C99R' $(30,40,58)$, and several advanced breeding lines $(29,30)$ have been shown to exhibit lower incidence of spotted wilt than 'Florunner' and other equally susceptible cultivars. The mechanism of resistance exhibited by these cultivars is unknown, but since thrips populations on resistant cultivars do not appear to be significantly lower than those on susceptible cultivars, differences in cultivar susceptibility are not thought to be due to differential preference by vectors $(25,28-31)$.

Planting date. Prior to severe outbreaks of spotted wilt in Georgia, planting date was found to influence the incidence of the disease on peanuts grown in southern Texas (47), where peanuts planted early and late in the normal planting season tended to have more spotted wilt than peanuts planted in the middle of the planting season, and those planted within a recommended "window" expressed less severe symptoms. Although actual planting dates are slightly different, a similar trend was 
found in Georgia (J. W. Todd, A. K. Culbreath, S. L. Brown, and J. P. Beasley, unpublished data). Optimum planting dates and the magnitude of the planting date effect vary slightly from year to year, but in general, avoiding early and late planting reduces incidence and severity of spotted wilt in Georgia. Again, the mechanism of the planting date effect is not totally understood, but midseason planting dates may avoid thrips population peaks (53). Although primary infection may occur throughout the growing season, young peanut tissue has been shown to be more susceptible to infection by Peanut bud necrosis virus (a tospovirus closely related to TSWV) than more mature tissue (21). Since planting dates that avoid synchronization of young peanut plants with peak thrips populations appear to significantly reduce TSWV infection levels, plant age may affect peanut susceptibility to TSWV in a similar manner.

Plant population. An association between low plant populations and high levels of spotted wilt was noted soon after the disease began to impact peanut production in Georgia, and more recently, research has confirmed this observation $(8,39)$. Brenneman and Walcott (8) found that $92 \%$ of the effect of plant population on yield was due to its indirect effect on spotted wilt. They characterized that effect as yield (lbs/A) = 3,728-31.5 (TSWV severity) + 176.4 (stand-2.9 plants/m). Individual peanut plants may have higher numbers of thrips feeding on them in low plant populations than in high plant populations (J. W. Todd and A. K. Culbreath, unpublished data), and therefore may have a higher probability of infection. In many cases, the actual number of infected plants per hectare may be nearly the same in low and high plant populations, but higher plant populations result in more uninfected plants per hectare, which helps compensate for yield losses on infected plants. Field survey data have also indicated that as populations drop below 13 plants per meter of row, spotted wilt severity progressively increases (S. L. Brown, unpublished data).

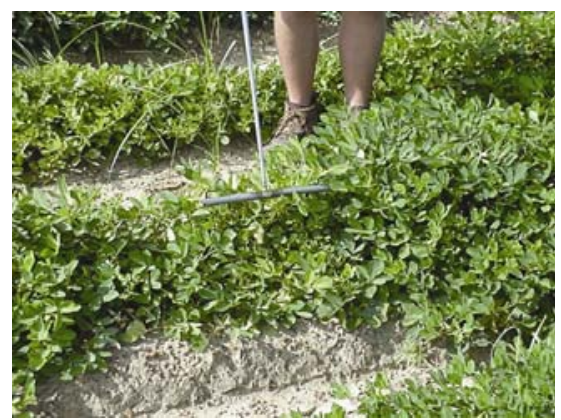

Fig. 1. Severe stunting in peanut resulting from early infection of Tomato spotted wilt virus (TSWV).
Use of phorate at planting. In general, the use of insecticides to control thrips vectors has been ineffective in suppressing spotted wilt $(34,53,55)$. Lowering vector populations with insecticides probably reduces secondary spread, but most infection is thought to be the result of primary transmission from overwintering and immigrating thrips (54). Despite the overall disappointing results with insecticides, infurrow applications of phorate granules have provided consistent, low-level suppression of spotted wilt (53). The mechanism of this suppression is not known, but the level of thrips control obtained with phorate is not greater than that obtained with other insecticides. Gallo-Meagher et al. (35) found oxidative stress in phoratetreated peanuts consistent with systemic acquired resistance mechanisms identified in other plant-pathogen associations (33). Their study (35) identified 22 genes that were turned on and 24 genes that were turned off in phorate-treated peanut plants compared with nontreated plants.

History of spotted wilt in a geographic area. The dynamic nature of TSWV in Georgia's diverse agricultural environment is very complex and not well understood. Incidence of spotted wilt has generally increased throughout the state since it was first discovered, but trends in geographical variation have been evident in annual surveys (S. L. Brown, unpublished data). Variation may be due to the abundance of host plants in the area (including symptomatic host crops such as peanut, tobacco, tomato, and pepper or other nonsymptomatic host crops), the presence of critical winter hosts (including volunteer peanuts) that provide a temporal bridge from one season to the next (24), or other poorly understood factors. Variation in spotted wilt pressure among geographical areas was strong during the early 1990s, but geographical variation declined as the disease became established throughout the peanut-producing areas of the southeastern United States.

Row pattern. Twin row spacing (18- to $25-\mathrm{cm}$, utilizing the same seeding rate per

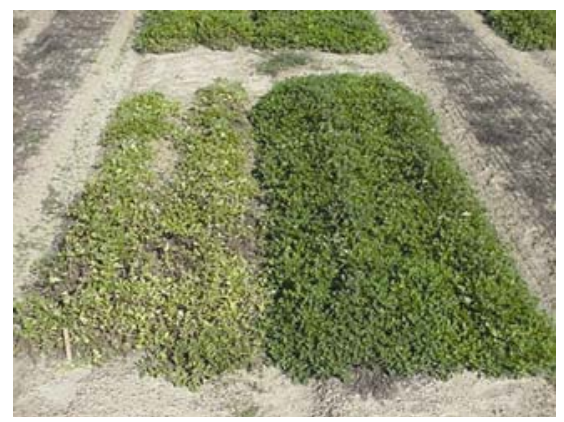

Fig. 2. Yellowing and general lateseason decline in peanut resulting from Tomato spotted wilt virus (TSWV) infection. Susceptible variety on the left versus a resistant breeding line on the right. hectare as single row spacing) has become increasingly popular in Georgia (Fig. 3). Research has shown a strong tendency for twin row patterns to have significantly higher yields, a one to two point increase in grade (percentage of total in-shell weight attributed to sound, mature kernels), significantly reduced spotted wilt severity, and significantly increased net returns per hectare $(2,3)$. The reason for reduced spotted wilt is not fully understood, but more rapid ground coverage in twin row patterns may affect the ability of thrips to locate a seedling host.

Tillage. Peanut growers utilize a variety of tillage methods, each with its own merits and disadvantages for a given situation. Strip tillage (tillage of a narrow band for the seed furrow, leaving the remainder of the land undisturbed) has some distinct advantages, including reduced soil erosion and reduced time and labor required for planting, but in some situations, yields have been disappointing. Previous studies have shown that peanuts grown in reduced tillage systems have less thrips damage $(23,46)$. Our on-farm observations during the early 1990s indicated a reduction in spotted wilt as well, and these observations have since been confirmed in replicated research plots $(4,44,48)$. Wheat straw applied to the soil surface prior to peanut emergence at the rate of $1,217,2,437$, and $4,876 \mathrm{~kg} / \mathrm{ha}$ to simulate different levels of crop residue resulted in 16, 34, and $51 \%$ reductions in thrips damage, respectively, and 21,49 , and $65 \%$ reductions in spotted wilt severity, respectively, compared with that of peanut grown on bare ground (S. L. Brown, unpublished data). The cause of this effect is unknown, but ground cover may interfere with thrips' ability to visually locate host plants. Slight reductions in spotted wilt do not always justify a change in tillage methods; however, tillage must be considered as a production practice that contributes to the overall variation in spotted wilt severity.

Use of Classic (chlorimuron) herbicide. Chlorimuron herbicide is used on approximately $20 \%$ of Georgia's peanut acreage for the control of Florida beggarweed (Desmodium tortuosum Swartz) that

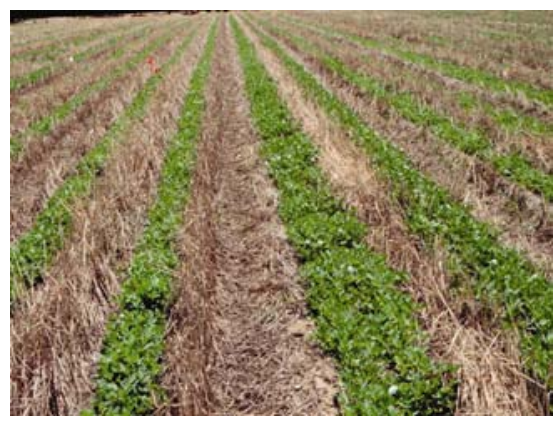

Fig. 3. Twin row (right) and single row (left) planting patterns for peanut. Both are planted in a field utilizing strip tillage into wheat residue. 
has escaped other management strategies. The chlorimuron label prohibits usage prior to 60 days after emergence (DAE). Field observations and replicated tests have demonstrated that chlorimuron applications can result in slightly increased spotted wilt severity and that applications during the 60 to $90 \mathrm{DAE}$ time period have the most damaging effect (51). Other peanut herbicides including imazapic, bentazon, paraquat, sulfentrazone, diclosulam, flumioxazin, and acifluorfen were evaluated and found to have no effect on spotted wilt severity.

Other possible contributing factors. Preliminary research and on-farm observations suggest that other factors may also impact incidence and severity of spotted wilt in peanut fields. Previous crops, immediately adjoining crops, irrigation practices, and weather have been suggested as factors that may influence disease severity, but research data are currently insufficient to define their impact relative to other known factors.

\section{Development and Modification of Spotted Wilt Risk Index}

The University of Georgia Tomato Spotted Wilt Risk Index for Peanuts was developed as a tool to help farmers assess the relative level of risk associated with individual peanut production scenarios. The index combines known factors influencing disease severity into a comprehensive but simple estimate of risk for a given production plan. It assigns a relative numeric weight to each factor so that an overall level of risk can be estimated. Numeric values were assigned so that higher point totals were indicative of higher levels of risk. While incidence cannot be predicted with total accuracy, by identifying highrisk situations, growers can avoid those combinations of cultural practices that are conducive to yield loss.

Throughout the development of the index, small plot research clearly demonstrated the unequal, yet generally additive, impact of the various cultural practices influencing spotted wilt severity (26). To

\section{Spotted Wilt Risk Index for Peanuts}

For each of the following factors that can influence the incidence of tomato spotted wilt, identify which option best describes the situation for an individual peanut field. An option must be selected for each risk factor. Add the index numbers associated with each choice to obtain an overall risk index value. Compare that number to the risk scale provided and identify the projected level of risk.

$\begin{array}{ll}\text { Peanut Variety }^{1} & \text { Risk In } \\ \text { Georgia Runner, Florunner, Sunrunner, Andru 93, MarcI } & \\ \text { GK7, NC V-11 } & \\ \text { Georgia Green, Southern Runner, Georgia Browne } & \end{array}$

Planting Date

Prior to April 10

April 11-20

April 21-30

May 1-15

May 16-25

After May 25

sk Index Points

Average Number of Plants Per Foot

Less than 1

1 to 3

More than 3

40

30

20

Previous Fall and Spring Volunteer Peanut Population

(in \& adjacent to field)

Abundant (greater than 5 per square yard) 10

Sparse (less than 5 per square yard)

None

\section{5}

0

Location of Field (County)

Tift, Worth, Turner, Colquitt, Grady, Thomas, Decatur,

Seminole, Miller, Brooks, Mitchell, Baker, Dougherty,

Cook, Berrien, Crisp, Lee, Coffee, Ben Hill, Irwin, Wilcox

Other Georgia counties

10

t-Plant Thrips Control

None or insecticide other than phorate (Thimet) Phorate (Thimet)

Total Points

Less than or equal to 50

55-85

Greater than or equal to 90

${ }^{1}$ Research data are not available for all varieties, but no other resistant varieties have been documented. If your variety is not shown here, add 40 points. ensure that results seen in controlled experiments were indeed occurring in whole field situations, on-farm validation studies were initiated with the release of the first version of the index. Surveys were conducted by visually rating spotted wilt severity (32) in selected peanut fields approximately 2 weeks prior to digging. Selection of most survey sites was random. However, in our effort to test the utility of the index in a wide range of situations, county agents were allowed to suggest specific fields representing a unique production practice or combination of practices. After disease ratings were taken in these fields, county extension agents were asked to gather all pertinent production information from the growers so that risk index values could be calculated. Risk index values were then plotted against spotted wilt severity. Regression analysis was conducted to examine the relationship between risk index value and final spotted wilt severity. Data were analyzed to the fourth degree polynomial using the SAS Proc GLM procedure (SAS Institute, Cary, $\mathrm{NC}$ ).

Original risk index - 1996. The index has undergone numerous modifications as more research was conducted and as disease epidemiology has been influenced by major changes in peanut production practices $(9,12,14-20)$. The original version of the risk index (Sidebar 1) consisted of six factors contributing to the overall level of risk (9). These were: cultivar, planting date, plant population, volunteer peanut population in the spring and fall prior to planting, geographic location by county, and at-plant insecticide usage. Volunteer peanut population was included because research indicated that volunteer peanuts were an important host aiding in the survival of viruliferous thrips during times when peanuts were not being commercially produced. Point values of options within a risk factor were established based on research that was available at the time. For example, research indicated that 'Southern Runner' and other similarly resistant cultivars normally exhibited about half the spotted wilt disease incidence found in 'Florunner' and similarly susceptible cultivars; and to reflect that relationship, susceptible varieties were assigned a point total twice that of the most resistant cultivars. Two cultivars that had displayed an intermediate level of spotted wilt severity were assigned an intermediate point value. Options within factors for which little or no quantitative data existed (such as volunteer peanut population and geographic location) were assigned point totals by consensus of the authors' opinions based on their personal observations.

The range of point values available among factors was weighted based on the degree of disease mitigation seen in independent experiments evaluating those factors. For example, since resistant cultivars 
had consistently reduced spotted wilt disease incidence or severity by approximately $50 \%$ in relation to susceptible cultivars, and phorate usually reduced severity by about $20 \%$, point values among these factors were weighted accordingly.

Possible point totals in the original risk index ranged from a minimum of 40 to a maximum of 105 . Point totals within that range were divided into high, moderate, and low risk ranges. Without data to confirm the validity of those ranges, it was decided that they would be defined in such a way that it would be impossible to obtain an overall low risk rating when a high-risk (40 point) cultivar had been selected. Similarly, it would be impossible to obtain a high risk rating when a low-risk (20 point) cultivar had been selected. The result was low risk situations being defined by point totals of less than 55, moderate risk situations being defined by point totals of 55 to 85 , and high risk situations being defined by point totals above 85 .

1997 risk index. Favorable results from small plot validation studies and an extensive on-farm validation project led to the conclusion to leave the 1997 version of the risk index largely unchanged from the original version (16). The 1997 index did, however, address some problems encountered in utilization of the original version. Volunteer peanut population proved to be a difficult variable for peanut producers to measure. Since both previous fall and spring populations were thought to be important, producers were asked to measure populations during two times of the year that they normally would not be in their fields. Furthermore, producers with crop rotations adequate to eliminate volunteer peanuts on their farm were still subject to the influence of high volunteer peanut populations on adjacent farms. Also, during the 1996 growing season, the use of county lines to differentiate high and low risk geographical areas proved to be less accurate than expected. While most of the severe spotted wilt disease incidence occurred in the designated high risk counties, there were numerous exceptions where major losses occurred outside the high risk counties. Due to the unpredictable expansion of geographical "hot spots" of disease incidence, it was concluded that county lines were not the best way to delineate high risk regions. To address these problems, a new factor considering the history of spotted wilt severity in a given area was created. It was thought that previous experiences with the disease, while not always indicative of what to expect the following year, would still tend to be a better indicator of future risk than county lines. Although volunteer peanut populations are still considered to be an important component of TSWV epidemiology, the variable was eliminated as an independent risk factor on the index and considered to be inherent in the spotted wilt disease history of a given area. Twenty-five points were assigned to fields with histories of greater than $50 \%$ spotted wilt severity, 15 points for fields with histories of severity ranging from 20 to $50 \%$, and 5 points for fields with histories of less than $20 \%$ severity.

Since validation studies showed a slightly larger than expected effect of plant population on disease severity, the point value for the lowest plant population was increased from 15 to 20 points. Adding to the maximum risk points possible on the index can dilute the impact of an individual risk factor on total risk. Therefore, as adjustments were made, we attempted to maintain the relative importance of the various risk factors.

1998 risk index. Based on further validation during the 1997 growing season, the five contributing components of the risk index remained unchanged on the 1998 version (17). Point values for some options under each of these components were modified, however, to reflect a growing body of data regarding their impacts on final disease severity. As overall disease severity increased in the mid-1990s, new comparisons of spotted wilt disease severity between susceptible and resistant cultivars revealed slightly greater differences than the 2:1 ratio previously noted. Therefore, point values for the more susceptible cultivars were increased from 40 to 50 , while point values for the most resistant cultivars remained at 20 . Point values for intermediate cultivars were increased from 30 to 35 . Point value ranges were similarly expanded for planting date, plant population, and at-plant insecticide usage as data indicated the range of impacts within these components were greater than previously estimated.

Spotted wilt disease history appeared to be a valid risk factor again in 1997, but the degree of geographical variation declined as disease incidence and severity generally increased in those areas that had previously escaped major losses. Point values within this component of the index were again changed to more accurately reflect observed variations. The new point scheme allowed 10 points to be added for fields in areas with traditionally high levels of spotted wilt disease and 10 points to be deducted for fields in areas with histories of exceptionally low incidence. Points were neither added nor subtracted for fields located in areas of average disease incidence.

1999 risk index. Due to mounting evidence of their impact on spotted wilt, row pattern and tillage were added as risk index components in 1999 (18). Single rows were assigned 15 points and twin rows were assigned 5 points, making the impact of row pattern on total risk equal to that of at-plant insecticide. Conventional tillage was assigned 10 points and strip tillage 5 points, making its impact slightly less. All other factors remained unchanged, and the possible point totals now ranged from 35 to 150 .

2000 risk index. Although seed supplies were limited, the new variety 'C-99R' was added to the risk index in 2000 (19). Based on variety tests indicating that ' $\mathrm{C}$ 99R' was exhibiting a level of resistance greater than all other commercially available varieties $(31,58)$, a new 15 -point category was created. Due to further evidence of the impact of tillage, the point value for conventional tillage was increased to 15 , making the impact of tillage on total risk equal to at-plant insecticide and row pattern. Due to a trend for later optimum planting dates, a slight modification was made in the planting date point values. The period with the lowest risk was extended from 1 to 15 May to 1 to 20 May. Also, the period with the second lowest point value was moved from just prior to the optimum period (21 to 30 April) to just after the optimum period (21 to 31 May). Possible point totals now ranged from 30 to 155 .

2001 to 2004 risk indices. Throughout the course of these studies, various attempts to address the risk inherent in geographical regions of Georgia proved to be difficult. The relative importance of this factor continued to decline, and this component of the index was dropped in the 2001 version. No other substantive changes were made to the 2001 version except to remove some varieties no longer available and add 'Gregory' (A. K. Culbreath, unpublished data) to the 20-point category (20).

Research demonstrating the impact of chlorimuron herbicide on spotted wilt lead to the inclusion of chlorimuron usage as a risk index factor in 2003 (14). Otherwise, recent modifications have been limited to the addition of new varieties as new research indicates their relative susceptibility to spotted wilt. The current (2004) version of the index is shown in Sidebar 2.

\section{Results of On-Farm Validation}

Results of the 1996 to 2000 on-farm surveys are shown in Figure 4A to E, respectively. In each graph, the range of the $\mathrm{x}$ axis represents the range of possible risk index values for that version of the index. In all years of the survey, the relationship between risk index value and spotted wilt severity was explained by a linear equation. $R^{2}$ values are displayed on each graph.

Due to the dynamic nature of spotted wilt epidemics, the risk index will always be subject to future refinements. Small plot experiments and on-farm surveys will continue to be used to validate the utility of the risk index, and point values will be modified as necessary. Recognizing the high degree of variation inherent in a diversity of production scenarios, our goal is to improve the predictability of spotted wilt severity relative to the cultural practices employed. Success in this endeavor 
can be measured in terms of improved $R^{2}$ values of plotted survey data, but with a preference of overestimating, rather than underestimating, incidence. In other words, we strive to minimize the number of outlying points on the upper left hand corner of our incidence versus index value plots, thereby reducing the number of fields having more disease than the index would predict. We have also tried to keep the range of index values as large as possible and to design a tool with goals that are realistically attainable. Keeping all these features in mind, revisions have improved the accuracy and utility of the index as demonstrated by plotting 1997 data (the data set with the most diverse production practices and the widest range of severity) using the 2001 version of the index (Fig. 5). Although $R^{2}$ values are similar, use of the 1997 version required a grower to select a set of cultural practices equating to the lower 10 index points in order to obtain a disease incidence lower than $20 \%$. With

\section{University of Georgia Spotted Wilt Risk Index for Peanuts}

For each of the following factors that can influence the incidence of tomato spotted wilt, identify which option best describes the situation for an individual peanut field. An option must be selected for each risk factor. Add the index numbers associated with each choice to obtain an overall risk index value. Compare that number to the risk scale provided and identify the projected level of risk.

$\begin{array}{lr} & \text { Risk Index } \\ \text { Peanut Variety }^{1} & \\ \text { Florunner, SunOleic 97R, Flavorunner 458 } & 50 \\ \text { Perry } & 40 \\ \text { NC-V 11, NC12C } & 35 \\ \text { AT-201 } & 30 \\ \text { GA Hi-OL } & 25 \\ \text { Georgia Green, Southern Runner, ViruGard, Gregory, VC2, } & 20 \\ \text { ANorden, Andru II } & 15 \\ \text { C-99R, Hull, Carver, GA02C, GA01R } & 10 \\ \text { DP1, AP3 } & \end{array}$

${ }^{1}$ Adequate research data are not available for all varieties. Additional varieties will be included as data to support the assignment of an index value are available.

Planting Date ${ }^{2}$

Prior to May 1

May 1-10

May 11-25

May 26-June 5

After June 5

${ }^{2}$ In those years when the normal date of planting for the first peanuts in your area is delayed due to inclement weather, these date ranges should be moved later by an equal amount. In most years, these date ranges will also vary slightly with latitude. Dates can be shifted 5 days earlier in the extreme southern counties and 5 days later in the extreme northern counties.

Plant Population (final stand, not seeding rate) ${ }^{3}$

Less than 3 plants per foot

3 to 4 plants per foot

More than 4 plants per foot

${ }^{3}$ Only plant during conditions conducive to rapid, uniform emergence. Less than optimum conditions at planting can result in poor stands or delayed, staggered emergence, both of which can contribute to increased spotted wilt. Note: a twin row is considered to be one row for purposes of determining number of plants per foot of row.

At-Plant Insecticide 4

None

Other than Thimet ${ }^{\circledR}$ 20G or Phorate ${ }^{\circledR}$ 20G

Thimet $^{\circledR}$ 20G, Phorate ${ }^{\circledR}$ 20G

${ }^{4}$ An insecticide's influence on the incidence of Tomato spotted wilt virus (TSWV) is only one factor among many to consider when making an insecticide selection. In a given field, nematode problems may overshadow spotted wilt concerns and decisions should be made accordingly.

\section{Row Pattern}

Single (32"-38")

Twin (7"-10")

Tillage

Conventional

Strip tillage into crop residue or winter cover

\section{5}

15

Classic ${ }^{\circledR}$ Herbicide

Classic $^{\circledR}$ applied

No Classic ${ }^{\circledR}$ applied

Total Points

Less than or equal to 65

70-110

Greater than or equal to 115
15

$\begin{array}{lc} & 15 \\ & 5 \\ & \\ & 15 \\ \text { ver } & 5 \\ & 5 \\ & 5 \\ \text { Risk of Losses Due to TSWV } & \\ \quad \text { Low } & \\ \text { Moderate } & \\ \text { High } & \end{array}$

the 2001 version, the lower 25 index points gave the same result, thereby giving the grower more flexibility in his selection of cultural practices.

\section{Grower Acceptance and Utilization}

The risk index has been featured in extension publications (17-20) and in the popular press $(10,13,49,52,61)$. It has been presented to thousands of producers at county level production meetings. An interactive version of the index is available on the internet at the site of "tomatospottedwiltinfo".

Surveys evaluating the impact of the risk index have been distributed to county agents in Georgia's peanut-producing counties biannually since 1987 (J. A. Baldwin and J. P. Beasley, unpublished data). These surveys provide evidence of how the risk index has mediated major changes in peanut production practices in Georgia. With 23 counties responding in 1997, results indicated that $80 \%$ of Georgia's peanut producers had changed at least one production practice to lower their risk of TSWV losses. Thirty-eight percent had changed two or more production practices, $24 \%$ had changed three or more production practices, and $9 \%$ had changed four production practices.

Perhaps the greatest of these changes has been in cultivar selection. Many more varieties are available to growers now than when TSWV was first found in Georgia. According to the 1987 survey, 'Florunner' was grown on over $80 \%$ of Georgia's peanut acreage, but by 1997, all available 'Georgia Green' and 'Southern Runner' seed were planted, accounting for approximately $30 \%$ of the total Georgia crop, and another $5 \%$ was planted to the newly released 'ViruGard'. In 1999 and 2000, over $90 \%$ of Georgia's total acreage was planted to 'Georgia Green', with most of the remainder in other partially resistant cultivars. This change constitutes the most rapid shift in peanut cultivar selection since 'Florunner' was introduced in 1969.

Significant shifts in planting date have also occurred due to adoption of the risk index. During the period from 1992 to 1996, an average of $47 \%$ of Georgia's peanut crop was planted in April. In 1999, 2000, and 2001, April plantings accounted for only 11,6 , and $4 \%$ of the total, respectively (1).

Other changes include increased use of twin-row planting patterns. Forty and fifty percent of Georgia's total peanut acreage was planted in twin rows in 2000 and 2001, respectively, compared with an average of only $10 \%$ during 1992 to 1996 . In Georgia, the percentage of peanut acreage treated with phorate is estimated to have increased from approximately $10 \%$ in 1992 to approximately $40 \%$ in 2000 , while use of the alternative aldicarb decreased from 57 to $40 \%$ during the same time pe- 
riod (37). Acreage utilizing strip tillage was approximately $20 \%$ in 2003 compared with approximately $5 \%$ in 1995 , and the percentage of Georgia peanut fields planted with at least $112 \mathrm{~kg}$ of seed per hectare increased from 30 to $40 \%$ during 1995 to 1997.

\section{Discussion}

Components of the risk index account for much of the variation found in spotted wilt severity, but not all of it. Greater variation should be expected when surveying a wide variety of situations where other influences are not constant as in small plot studies. Acknowledging the nature of this variation, on-farm surveys continue to show that fields defined as high-risk by the index are much more likely to have high levels of spotted wilt than fields defined as low-risk. Grower adoption of the risk index is evident in the latter years of the

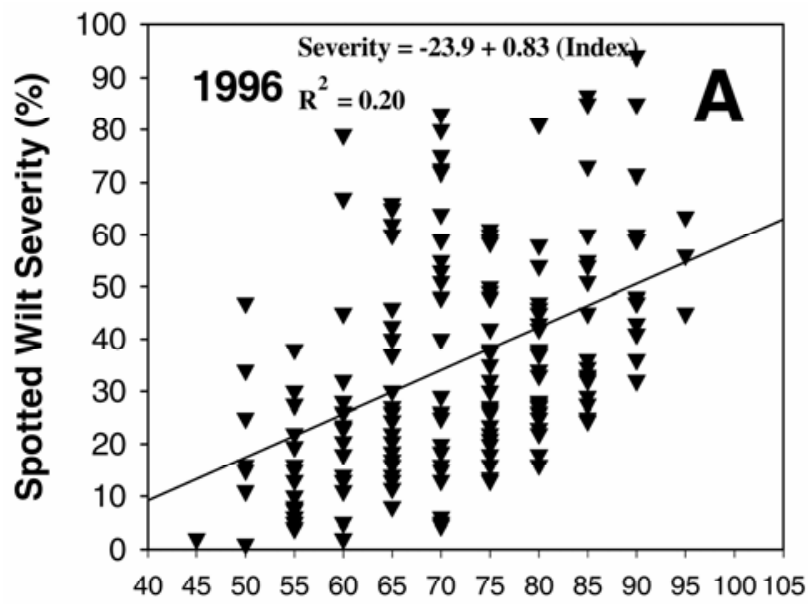

1996 Risk Index Value

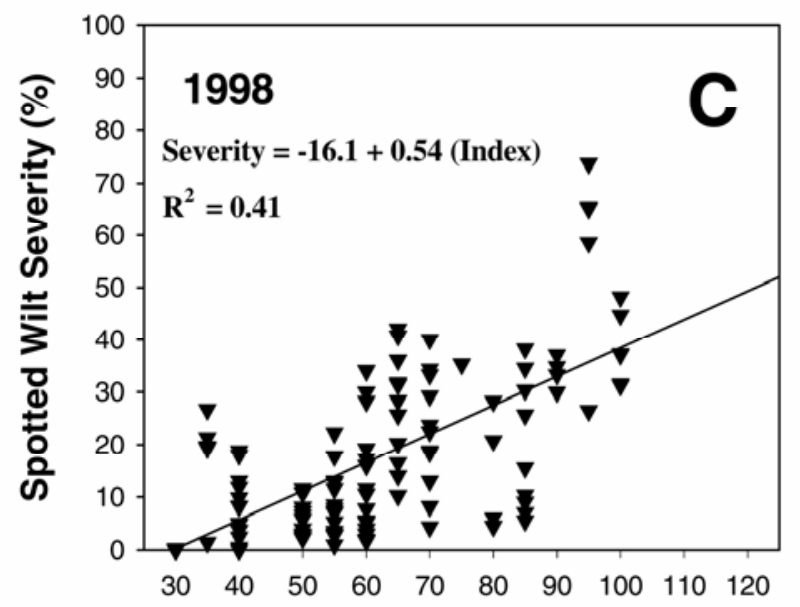

1998 Risk Index Value

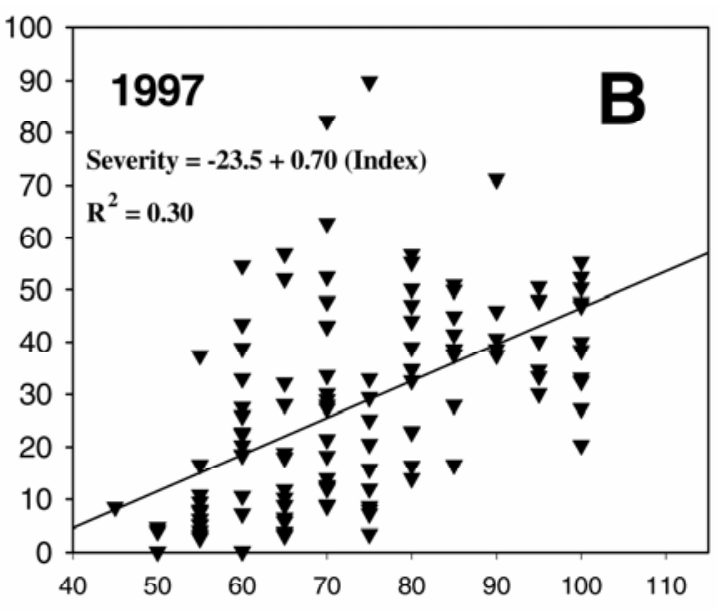

1997 Risk Index Value

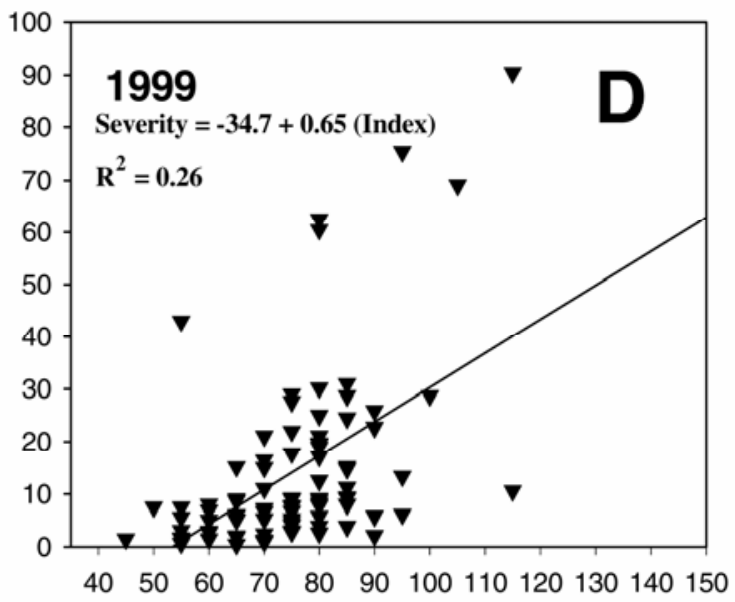

1999 Risk Index Value

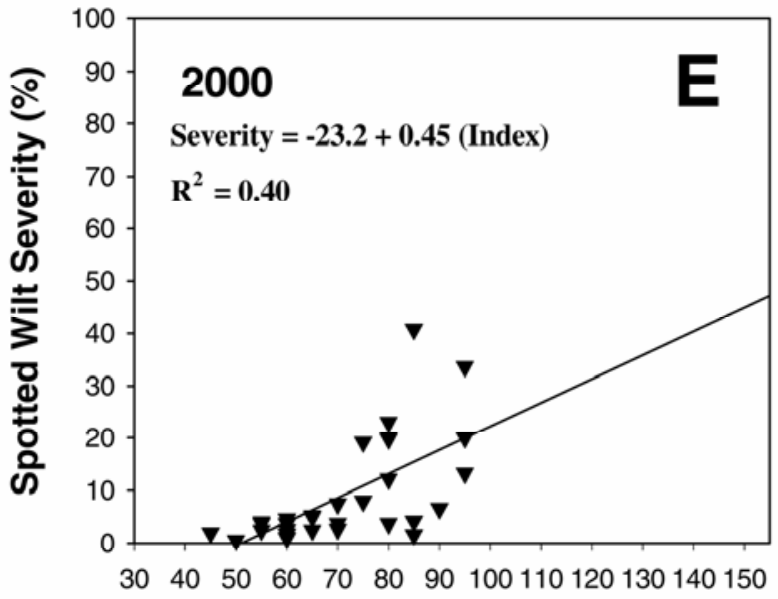

\section{Risk Index Value}

Fig. 4. Results of 1996 to 2000 on-farm index validation. The range of risk index values in each graph represents the range of values available in that year's version of the index. 
survey when very few high-risk fields were found. High-risk situations intentionally created in small plot studies continue to show levels of spotted wilt severity exceeding $60 \%$ (J. W. Todd, unpublished data), suggesting that spotted wilt pressure has not subsided, but that recent reductions in severity are the result of modifications in production practices.

Based on surveys of Georgia county agents in peanut producing areas, the 5year (1995 to 1999) average increase in peanut yield due to adoption of practices for management of spotted wilt is nearly $280 \mathrm{~kg} / \mathrm{ha}$, which represents $10 \%$ of the $5-$ year average yield over the same time period (1). With multiple index factors used on more than $80 \%$ of Georgia's 217,890 harvested peanut hectares and an average price of $\$ 0.581$ per $\mathrm{kg}$, the economic impact of adopting the spotted wilt risk index to Georgia peanut producers totaled \$28 million in 1999 alone.

This novel approach to integrated pest management has been successful because factors affecting spotted wilt severity and their relative importance could be determined. Success was also dependent upon the impact of these factors being additive. In our experience, we found cooperation between research and extension scientists and a willingness to modify previous versions of the index to be critical to the success of the project. When similar conditions prevail, approaches similar to ours may also be successful in the management of other pest problems on other crops.

Subsequent to development of the tomato spotted wilt risk index, similar techniques were devised to develop other risk indices. Scientists in Virginia and North Carolina have made minor modifications in our spotted wilt risk index to better fit their environmental conditions (43). Using criteria such as peanut cultivar, field history, soil texture, drainage class, and planting date, they have also developed an index to define relative risks of factors con- tributing to southern corn rootworm (Diabrotica umdecimpuctatum howardi Barber) damage to peanut (42). A risk index for other foliar and soilborne peanut diseases is now under development in Georgia (45), and one to help peanut growers assess the risks of changing from conventional to conservation tillage has been released by North Carolina State University (62). Research also is underway to develop a risk index to quantify factors contributing to aflatoxin contamination in peanuts in the southeastern United States (7).

\section{Literature Cited}

1. Anonymous. National Agricultural Statistics Service. U.S. Dep. Agric. N.A.S.S. Online publication.

2. Baldwin, J. A., Beasley, J. P., and Brown, S. L. 1999. Yield, grade and tomato spotted wilt incidence of five peanut cultivars in response to twin versus single row planting patterns. Proc. Am. Peanut Res. Educ. Soc. 31:72.

3. Baldwin, J. A., Culbreath, A. K., and Jones, S. 1999. Peanut cultivar response when planted in either twin or single row patterns by strip tillage or no tillage methods. Page 87 in: Proc. Southern Conservation Tillage Conf. Sustainable Agric. 22nd

4. Baldwin, J. A., Todd, J. W., Weeks, J. R., Gorbet, D. W., Culbreath, A. K., Luke-Morgan, A. S., Fletcher, S. M., and Brown, S. L. 2001. A regional study to evaluate tillage, row patterns, in-furrow insecticides and planting dates on the yield, grade and tomato spotted wilt virus incidence of the Georgia Green peanut cultivar. Pages 26-34 in Proc. Southern Conservation Tillage Conf. Sustainable Agric. 24th.

5. Black, M. C., and Smith, D. H. 1987. Spotted wilt and rust reactions in south Texas among selected peanut genotypes. Proc. Am. Peanut Res. Educ. Soc. 19:31.

6. Boote, K. J. 1982. Growth stages of peanut (Arachis hypogaea L.). Peanut Sci. 9:35-39.

7. Bowen, K. L., Beasley, J. P., and Shaw, J. N. 2003. Field factors contributing to aflatoxin contamination in peanut in the southeastern U.S. (Abstr.) Phytopathology 93:S10.

8. Brenneman, T., and Walcott, R. 2001. Defining the relationship between plant stand, tomato spotted wilt and pod yield from peanut seed treatment trials. Proc. Am. Peanut Res. Edu. Soc. 33:21-22.

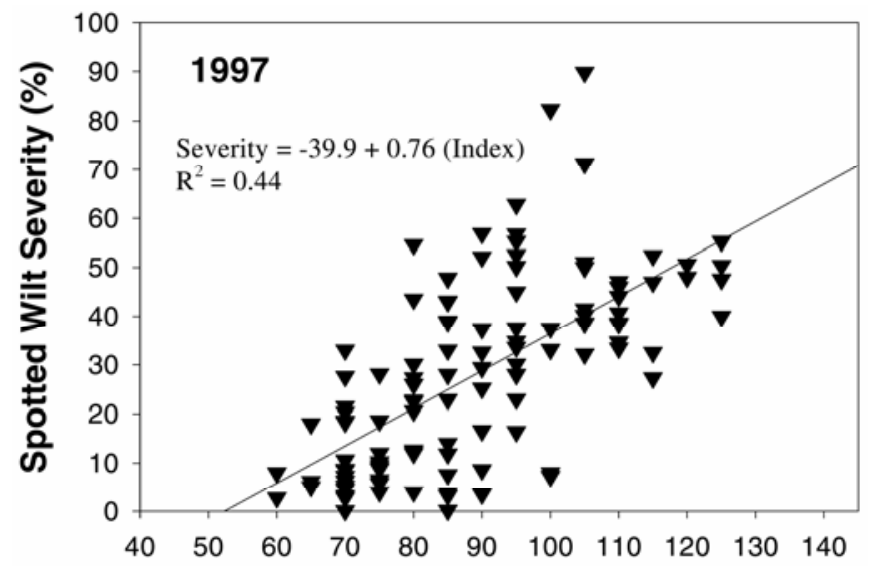

2001 Risk Index Values

Fig. 5. 1997 on-farm validation data plotted using 2001 risk index values. Compare with Figure 4B, which is the same data plotted using 1997 risk index values.
9. Brown, S. L. 1996. Some important facts about TSWV. 1996 Peanut Update. Univ. Ga. Coop. Ext. Serv. Publ. CSS-96-05. Athens, GA.

10. Brown, S. L. 1997. Management tips to reduce your losses from spotted wilt. Peanut Grower. Nov./Dec. 1997.

11. Brown, S. L., Todd, J. W., and Culbreath, A. K. 1996. Effect of selected cultural practices on incidence of tomato spotted wilt virus and populations of thrips vectors in peanuts. Acta Hortic. 431:491-498.

12. Brown, S. L., Todd, J. W., Culbreath, A. K., Baldwin, J. A., Beasley, J. P., and Kemerait, R. C. 2002. Managing spotted wilt of peanut. Univ. Ga. Coop. Ext. Serv. Bull. 1165, Athens, GA.

13. Brown, S. L., Todd, J. W., Culbreath, A. K., Baldwin, J. A., Beasley, J. P., Kemerait, R., and Pappu, H. 2001. Tomato spotted wilt of peanut: Identifying and avoiding high-risk situations. Peanut Grower 13(4):12-15.

14. Brown, S. L., Todd, J. W., Culbreath, A. K., Baldwin, J. A., Beasley, J. P., Kemerait, R. C., and Prostko, E. P. 2003. Minimizing spotted wilt of peanut. Univ. Ga. Coop. Ext. Serv. Bull. 1165, Athens, GA

15. Brown, S. L., Todd, J. W., Culbreath, A. K., Baldwin, J. A., Beasley, J. P., Kemerait, R. C., Prostko, E. P., and Smith, N. B. 2004. Minimizing spotted wilt of peanut. Univ. Ga. Coop. Ext. Serv. Bull. 1165, Athens, GA.

16. Brown, S. L., Todd, J. W., Culbreath, A. K., Baldwin, J. A., Beasley, J. P., and Pappu, H. R. 1997. The tomato spotted wilt risk index Identifying and avoiding high risk situations. Univ. Ga. Coop. Ext. Serv. Bull. 1165, Athens, GA.

17. Brown, S. L., Todd, J. W., Culbreath, A. K., Baldwin, J. A., Beasley, J. P., and Pappu, H. R. 1998. The tomato spotted wilt risk index Identifying and avoiding high risk situations. Univ. Ga. Coop. Ext. Serv. Bull. 1165, Athens, GA.

18. Brown, S. L., Todd, J. W., Culbreath, A. K., Baldwin, J. A., Beasley, J. P., and Pappu, H. R. 1999. The tomato spotted wilt risk index Identifying and avoiding high risk situations. Univ. Ga. Coop. Ext. Serv. Bull. 1165, Athens, GA.

19. Brown, S. L., Todd, J. W., Culbreath, A. K., Baldwin, J. A., Beasley, J. P., and Pappu, H. R. 2000. The tomato spotted wilt risk index Identifying and avoiding high risk situations. Univ. Ga. Coop. Ext. Serv. Bull. 1165, Athens, GA.

20. Brown, S. L., Todd, J. W., Culbreath, A. K., Baldwin, J. A., Beasley, J. P., and Pappu, H. R. 2001. The tomato spotted wilt risk index Identifying and avoiding high risk situations. Univ. Ga. Coop. Ext. Serv. Bull. 1165, Athens, GA.

21. Buiel, A. A. M., and Parleviet, J. E. 1996 Mature plant and tissue resistance in the groundnut-peanut bud necrosis virus system. Euphytica 91:213-217.

22. Camann, M. A., Culbreath, A. K., Pickering, J., Todd, J. W., and Demski, J. W. 1995. Spatial and temporal patterns of spotted wilt epidemics in peanut. Phytopathology 85:879-885.

23. Campbell, W. V., Sullivan, G. A., and Rogister, E. W. 1985. Comparison of pests and pest damage in no-till and conventionally-planted peanuts. Proc. Am. Peanut Res. Educ. Soc. 17:61.

24. Chamberlin, J. R., Todd, J. W., Beshear, R. J., Culbreath, A. K., and Demski, J. W. 1992 Overwintering hosts and wing form of thrips (Frankliniella spp.) in Georgia: Implications for management of spotted wilt disease. Environ. Entomol. 21:121-128.

25. Culbreath, A. K., Todd, J. W., Branch, W. D., Brown, S. L., Demski, J. W., and Beasley, J. P. 1994. Effect of new cultivar Georgia Browne on epidemics of spotted wilt. Plant Dis. 


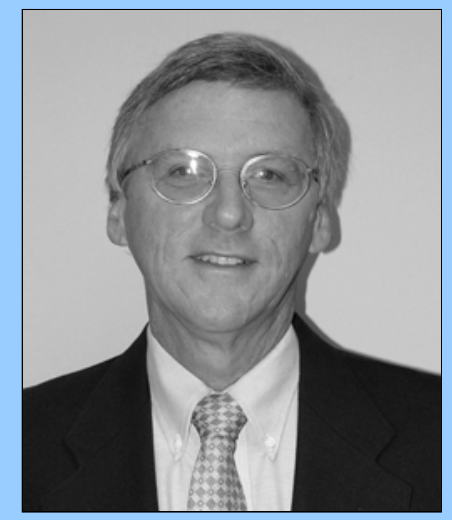

Steve L. Brown

Dr. Brown received his B.S. degree in botany and M.S. degree in plant pathology from Auburn University. His Ph.D. in entomology was awarded by Clemson University. $\mathrm{He}$ is currently professor and extension entomologist in the Department of Entomology at the University of Georgia and has extension responsibilities in peanuts and stored agricultural products. $\mathrm{He}$ also serves as extension coordinator for his department. Dr. Brown has received the University of Georgia's D.W. Brooks Award for Excellence in Extension and the Award of Excellence in Education from the American Peanut Research and Education Society.

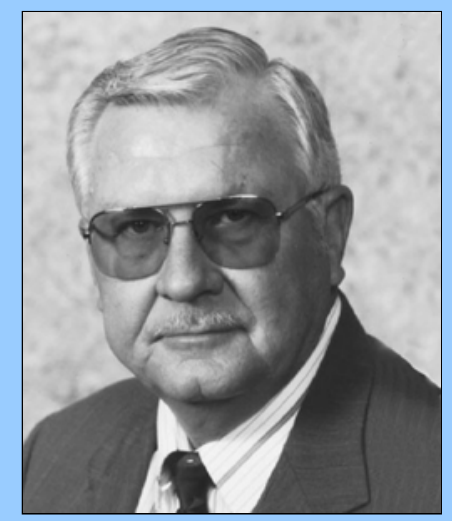

Dan W. Gorbet

Dr. Gorbet received his B.S. degree from Texas A\&I University and his M.S. and Ph.D. degrees from Oklahoma State University. $\mathrm{He}$ is currently professor of agronomy at the University of Florida and is located at the North Florida Research and Education Center in Marianna. He conducts the University of Florida peanut breeding and genetics program, focusing on disease and other pest resistance, yield, quality, oil chemistry, agronomic adaptation, and other factors. Dr. Gorbet has developed 16 peanut cultivars with various traits for maturity, disease resistance, flavor, and oil chemistry. $\mathrm{He}$ is co-inventor of three U.S. utility patents on peanut oil chemistry.

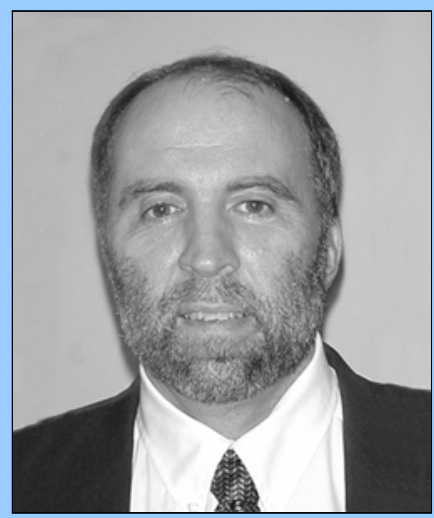

Albert K. Culbreath

Dr. Culbreath received his B.S. in botany and his M.S. in plant pathology from Auburn University, and his Ph.D. in plant pathology from North Carolina State University. In 1989, he joined the faculty of the University of Georgia as an assistant professor in the Department of Plant Pathology, located at the Coastal Plain Experiment Station in Tifton. He was promoted to associate professor in 1994 and to professor in 1999. His primary research areas are epidemiology and integrated management of foliar fungal diseases and tomato spotted wilt of peanut. He has served as president of the Southern Division of the APS and as APS Councilor from the Southern Division.

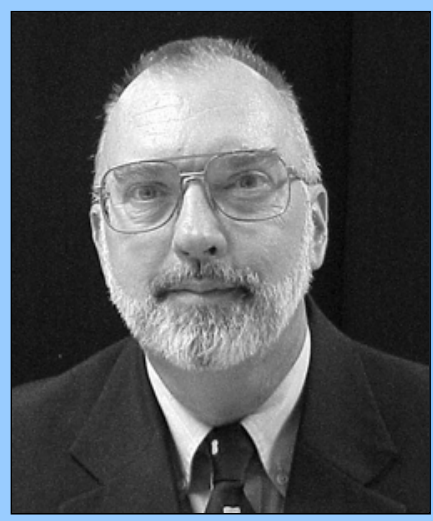

John A. Baldwin

Dr. Baldwin is extension agronomistpeanuts in the Crop and Soil Sciences Department of the University of Georgia. $\mathrm{He}$ has the responsibility of developing and implementing a statewide educational program in peanut production. His accomplishments include developing harvest maturity assessments for improving yield and quality, educational programs in peanut quality enhancement, and work with production methodologies to improve production efficiency and reduce costs of production. Dr. Baldwin is a Fellow of the American Peanut Research and Education Society.

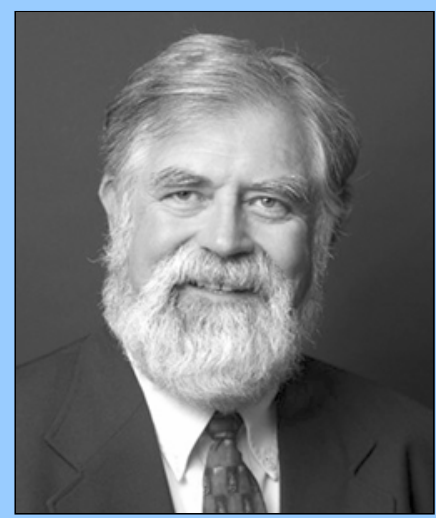

James W. Todd

Dr. Todd is professor of entomology in the Department of Entomology at the University of Georgia and has researched pest management of soybeans and peanuts since 1968 . He received his B.S. and M.S. degrees from Auburn University in entomology, agronomy, and horticulture and a Ph.D. in entomology and agronomy from Clemson University in 1973. He is a Fellow in the American Peanut Research and Education Society and is a past president of the southeastern branch of the Entomological Society of America. He was regional coordinator of the USDA's Pesticide Impact Assessment Program from 1986 to 1988, and has served on numerous review panels for the USDA and academia.

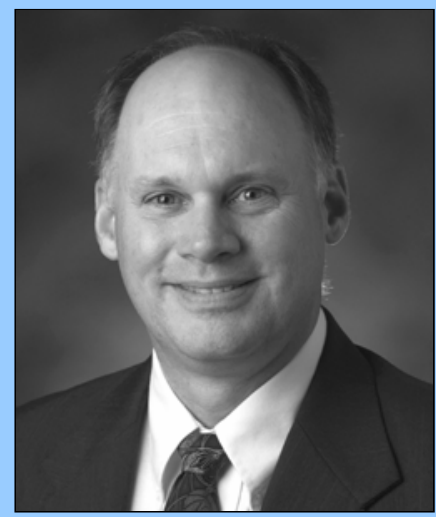

John P. Beasley, Jr.

Dr. Beasley is professor and extension peanut agronomist in the Crop and Soil Sciences Department of the University of Georgia. He received his B.S. degree in agronomy and soils from Auburn University in 1979, his M.S. degree from Oklahoma State University in Agronomy (peanut breeding) in 1981, and his Ph.D. in crop science (cotton breeding and genetics) from Louisiana State University in 1985. Dr. Beasley has been named a Fellow of the American Society of Agronomy and a Fellow of the American Peanut Research and Education Society. He has received the Award of Excellence in Education (Extension) from the American Peanut Research and Education Society. 
78:1185-1189

26. Culbreath, A. K., Todd, J. W., and Brown, S. L. 2003. Epidemiology and mangagement of tomato spotted wilt in peanut. Annu. Rev. Phytopathol. 41:53-75.

27. Culbreath, A. K., Todd, J. W., and Demski, J. W. 1992. Productivity of Florunner peanut infected with tomato spotted wilt virus. Peanut Sci. 19:11-14.

28. Culbreath, A. K., Todd, J. W., and Demski, J. W. 1992. Disease progress of tomato spotted wilt virus in Florunner and Southern Runner peanut cultivars. Phytopathology 82:766-771.

29. Culbreath, A. K., Todd, J. W., Gorbet, D. W., Branch, W. D., Sprenkel, R. K., Shokes, F. M., and Demski, J. W. 1996. Disease progress of spotted wilt in selected peanut cultivars and advanced breeding lines. Plant Dis. 80:70-73.

30. Culbreath, A. K., Todd, J. W., Gorbet, D. W., Brown, S. L., Baldwin, J. A., Pappu, H. R., Holbrook, C. C., and Shokes, F. M. 1999. Response of early, medium, and late maturing peanut breeding lines to field epidemics of tomato spotted wilt. Peanut Sci. 26:100-106.

31. Culbreath, A. K., Todd, J. W., Gorbet, D. W., Brown, S. L., Baldwin, J., Pappu, H. R., and Shokes, F. M. 2000. Reaction of peanut cultivars to spotted wilt. Peanut Sci. 27:35-39.

32. Culbreath, A. K., Todd, J. W., Gorbet, D. W., Shokes, F. M., and Pappu, H. R. 1997. Field response of new peanut cultivar UF91108 to tomato spotted wilt virus. Plant Dis. 81:14101415.

33. Friedrich, L., Vernooij, B., Negrotto, D., Nye, G., Uknes, S., Ward, E., Kessmann, H., and Ryals, J. 1993. Requirements of salicylic acid for the induction of systemic acquired resistance. Science 261:754-756.

34. Funderburk, J., Olsen, S., and Puche, H. 1990. Insecticidal control of thrips in tomato with implications for management of TSWV. Pages 31-40 in: Proc. Fla. Tomato Instit. W. M. Hall ed.

35. Gallo-Meagher, M., Chengalrayan, K., Davis, J. M., and MacDonald, G. E. 2001. Phorate-induced peanut genes that may condition acquired resistance to tomato spotted wilt. Proc. Am. Peanut Res. Educ. Soc. 33:29.

36. German, T. L., Ullman, D. E., and Moyer, J. W. 1992. Tospoviruses: Diagnosis, molecular biology, phylogeny, and vector relationships. Annu. Rev. Phytopathol. 30:315-348.

37. Gianessi, L. P., and Silvers, C. S. 2000. Trends in Crop Pesticide Usage: Comparing 1992 and
1997. National Center for Food and Agricultural Policy. Online publication.

38. Goldbach, R., and Peters, D. 1994. Possible causes of the emergence of tospovirus diseases. Sem. Virol. 5:113-120.

39. Gorbet, D. W., and Shokes, F. M. 1994. Plant spacing and tomato spotted wilt virus. Proc. Am. Peanut Res. Educ. Soc. 26:50.

40. Gorbet, D. W., and Shokes, F. M. 2002. Registration of 'C-99R' peanut. Crop Sci. 42:2207.

41. Hagan, A. K., Weeks, J. R., French, J. C., Gudauskas, R. T., Mullen, J. M., Gazaway, W. S., and Shelby, R. 1990. Tomato spotted wilt virus in peanut in Alabama. Plant Dis. 74:615.

42. Herbert, D. A., Petka, W. J., and Brandenburg, R. L. 1997. A risk index for determining insecticide treatment for southern corn rootworm in peanut. Peanut Sci. 24:128-134.

43. Hurt, C., Brandenburt, R., Jordan, D., Shew, B., Isleib, T., Linker, M., Herbert, A., Phipps, P., Swann, C., and Mozingo, W. 2003. Managing tomato spotted wilt virus in peanut in North Carolina and Virginia. N.C. Coop. Ext. Serv., AG-638.

44. Johnson, W. C., III, Brenneman, T. B., Baker, S. H., Johnson, A. W., Sumner, D. R., and Mullinex, B. G., Jr. 2001. Tillage and pest management considerations in a peanut-cotton rotation in the southeastern coastal plain. Agron. J. 93:570-576

45. Kemerait, R. C., Brenneman, T. B., and Culbreath, A. K. 2004. A risk index for leaf spot and soilborne diseases of peanut in Georgia, 2003. 2003 Georgia Peanut Res. Ext. Rep., UGA/CPES Res.-Ext. Publ. No. 2004, Athens, GA.

46. Minton, N. A., Csinos, A. S., Lynch, R. E., and Brenneman, T. B. 1991. Effects of two cropping and two tillage systems and pesticides on peanut pest management. Peanut Sci. 18:41-46.

47. Mitchell, F. L., Smith, J. W., Crumley, C. R., and Stewart, J. W. 1991. Management of tomato spotted wilt virus in South Texas peanut fields. Proc. Am. Peanut Res. Educ. Soc. 23:76.

48. Monfort, W. S., Culbreath, A. K., Stevenson, K. L., Brenneman, T. B., Gorbet, D. W., and Phatak, S. 2004. Effects of reduced tillage, resistant cultivars and reduced fungicide inputs on progress of early leaf spot of peanut (Arachis hypogaea L.) Plant Dis. 88:858-864.

49. Nelin, M. 1997. The tomato spotted wilt virus risk index. Peanut Grower 9(3):S1-S8

50. Peters, D., Wijkamp, I., van de Wetering, F., and Goldbach, R. 1996. Vector relations in the transmission and epidemiology of tospoviruses. Acta Hortic. 431:29-43.

51. Prostko, E. P., Kemerait, R. C., Johnson, W. C. III, Brecke, B. J., and Brown, S. N. 2002. The influence of Classic on tomato spotted wilt virus of peanut. Proc. Am. Peanut Res. Educ. Soc. 34:99.

52. Sanders, S. 1996. Tomato spotted wilt virus what can peanut farmers do? AgriSearch, Univ. Ga. 10(3):1

53. Todd, J. W., Culbreath, A. K., and Brown, S. L. 1996. Dynamics of vector populations and progress of spotted wilt disease relative to insecticide use in peanuts. Acta Hortic. 431:483-490.

54. Todd, J. W., Culbreath, A. K., Pappu, H. R., and Brown, S. L. 1997. Thrips as tospovirus vectors in peanut. Proc. Am. Peanut Res. Educ. Soc. 29:17.

55. Todd, J. W., Culbreath, A. K., Rogers, D., and Demski, J. W. 1994. Contraindications of in secticide use relative to vector control for spotted wilt disease in peanut. Proc. Am. Peanut Res. Educ. Soc. 26:42.

56. Ullman, D. E., German, T. L., Sherwood, J. L., Wescot, D. M., and Cantone, F. A. 1993. Tospovirus replication in insect vector cells: Immuno-cytochemical evidence that the nonstructural protein encoded by the S RNA of tomato spotted wilt tospovirus is present in thrips vector cells. Phytopathology 83:456463.

57. van de Wetering, F., Goldbach, R., and Peters, D. 1996. Tomato spotted wilt tospovirus ingestion by first instar larvae of Franliniella occi dentalis is a prerequisite for transmission. Phytopathology 86:900-905.

58. Wells, M. L., Culbreath, A. K., Todd, J. W. Brown, S. L., and Gorbet, D. W. 2002. A regression approach for comparing field resistance of peanut cultivars to tomato spotted wilt virus. Crop Prot. 21:467-474.

59. Wijkamp, I., Van Lent, J., Kormelink, R. Goldbach, R., and Peters, D. 1993. Multiplication of tomato spotted wilt virus in its insect vector, Frankliniella occidentalis. J. Gen. Virol. 74:341-349.

60. Williams-Woodard, J. 2001. 2000 Georgia plant disease loss estimates. Univ. Ga. Coop. Ext. Serv. Publ. Pathol. 01-001, Athens, GA.

61. Yancy, C. 1997. Refining the risk index. Peanut Farmer 33(3):36-38

62. Yancy, C. 2004. New peanut advisory in place. Southeast Farm Press. 31(2):1 